\title{
Depth and Sowing Rate as Factors Affecting the Development, Plant Density, Height and Yielding for Two Faba Bean (Vicia faba L. Var. Minor) Cultivars
}

\author{
Waldemar Helios ${ }^{1}\left(\mathbb{D}\right.$, Anna Jama-Rodzeńska ${ }^{1, *} \mathbb{0}$, Magdalena Serafin-Andrzejewska ${ }^{1}\left(\mathbb{D}\right.$, Andrzej Kotecki ${ }^{1}$, \\ Marcin Kozak ${ }^{1}$, Piotr Zarzycki ${ }^{2}$ and Leszek Kuchar ${ }^{3}$ \\ 1 Institute of Agroecology and Plant Production, Wrocław University of Environmental and Life Sciences, \\ Grunwaldzki Sq. 24 A, 50-363 Wrocław, Poland; waldemar.helios@upwr.edu.pl (W.H.); \\ magdalena.serafin-andrzejewska@upwr.edu.pl (M.S.-A.); andrzej.kotecki@upwr.edu.pl (A.K.); \\ marcin.kozak@upwr.edu.pl (M.K.) \\ 2 Cattle Breeding Przerzeczyn Zdrój, Gilów 120 A, 58-231 Niemcza, Poland; piotr.zarzycki@przerzeczyn.com.pl \\ 3 Department of Applied Mathematics, Wrocław University of Environmental and Life Sciences, \\ Grunwaldzka St. 53, 50-357 Wrocław, Poland; leszek.kuchar@upwr.edu.pl \\ * Correspondence: anna.jama@upwr.edu.pl
}

check for updates

Citation: Helios, W.;

Jama-Rodzeńska, A.;

Serafin-Andrzejewska, M.;

Kotecki, A.; Kozak, M.; Zarzycki, P.;

Kuchar, L. Depth and Sowing Rate as

Factors Affecting the Development,

Plant Density, Height and Yielding

for Two Faba Bean (Vicia faba L. Var.

Minor) Cultivars. Agriculture 2021, 11,

820. https://doi.org/10.3390/

agriculture 11090820

Academic Editors: Ciro

Antonio Rosolem and Urs Feller

Received: 5 July 2021

Accepted: 26 August 2021

Published: 28 August 2021

Publisher's Note: MDPI stays neutral with regard to jurisdictional claims in published maps and institutional affiliations.

Copyright: (c) 2021 by the authors. Licensee MDPI, Basel, Switzerland. This article is an open access article distributed under the terms and conditions of the Creative Commons Attribution (CC BY) license (https:/ / creativecommons.org/licenses/by/ $4.0 /)$.
Abstract: Sowing depth and density are factors which affect development and yielding due to their influence on plants' competition for water, light and nutrients. The aim of the present research was to evaluate the effect of sowing depth $(5$ and $8 \mathrm{~cm})$ and density $\left(45,60,75\right.$ seeds $\left.\mathrm{m}^{2}\right)$ on the development and yield of two morphotypes of faba bean. Higher plants were found at $8 \mathrm{~cm}$ sowing depth in 2011 and 2013, in turn, plant density before harvest, at $5 \mathrm{~cm}$ in 2011 and $8 \mathrm{~cm}$ in 2013. The greatest seed yield was observed while sowing shallower in $2011\left(4.50 \mathrm{t} \mathrm{ha}^{-1}\right)$ and 2012 (6.62 $\mathrm{t} \mathrm{ha}^{-1}$ ), and deeper in 2013 (3.53 $\mathrm{t} \mathrm{ha}^{-1}$ ). Cultivar played in important role in shaping plant height and seed yield in all years of the experiment, as well as in straw yield in 2012. Bobas characterized by the greatest seed productivity in all years of experiment compared to Granit, as well as quantity of straw yield in 2011 and 2012 (3.51 and $4.88 \mathrm{tha}^{-1}$, respectively) and therefore can be recommended for cultivation. Taking into account plant density before harvest in 2011-2013 as well as straw yield in 2011 and 2013, the most favorable sowing density is 75 seeds per $\mathrm{m}^{2}$.

Keywords: sowing depth; sowing density; determinate and indeterminate cultivar; development; seed yield; straw yield; plant height; plant density before harvest

\section{Introduction}

Faba bean ( $V$. faba L.) is the fourth most important pulse crop in the world used for grain, vegetables, animal feed, and green manure cultivated in 58 countries over a large area $[1,2]$.

The genotypes of $V$. faba are classified into three main botanical varieties according to seed size: $V$. faba var. major with large seeds, $V$. faba var. minor with small seeds, and $V$. faba var. equina with medium seeds [3]. The first two varieties are relevant in European agriculture. Faba bean seed size is an important trait in determining market and consumption forms. V. faba var. major is commonly used for food (either as fresh green vegetable or dry seeds). V. faba var. minor and var. equina are mostly used for animal feed [3]. Seeds of the faba bean are regarded as a valuable protein crop, which ranks seventh in terms of protein source found in legumes [4].

Faba bean is adapted to various habitat conditions. This crop contributes to yield improvement, reduction of pest and diseases, and weed control in cereal production. Moreover, it enriches the soil with organic compounds and nutrients. According to Landry et al. [5] and Jensen et al. [6], the average $\mathrm{N}$ fixation globally can gain $153 \mathrm{~kg}$ shoot $\mathrm{N} \mathrm{ha}^{-1}$, while Galloway et al. [7] concluded that faba bean can fix $50-330 \mathrm{~kg} \mathrm{~N} \mathrm{hm}^{-2}$. 
Study by Neugschwandtner et al. [8] showed that faba bean can fix up to $200 \mathrm{~kg} \mathrm{~N}^{-1}$ and legume residues into the soil, improving soil properties, such as organic matter content, density, porosity, and water capacity [2,9]. The ability to fix atmospheric nitrogen allows to reduce the use of mineral fertilisers by as much as $20-25 \%$ [10]. The amount of nutrients in legume crop residues is around $35 \mathrm{~kg} \mathrm{ha}^{-1} \mathrm{~K}$ and $25 \mathrm{~kg} \mathrm{ha}^{-1} \mathrm{P}$, and therefore its use in crop rotation is highly desirable [11].

One of the factors affecting economics (cost of material seed), biomass, yield and its components is sowing density. It determines the number of seeds per square meter, which in turn is responsible for the area available for each future plant [12]. There are divergences in the available literature in the determination of optimal faba bean sowing density $[1,13]$. The available literature related to the response of faba beans to sowing density presents a wide range of densities [14,15]. Optimum sowing density as a result of the correct sowing rate for various faba bean varieties can range from 10 to 100 plants $\mathrm{m}^{-2}$. However, Mwanamwenge et al. [16] claimed that the optimal sowing densities for faba beans have not been yet determined. There is a need to determine the sowing seed rate depending on seed size and different legume morphotypes (determinate and indeterminate) under different sowing conditions.

Another factor effect on yield is sowing depth, something which has a significant effect on the ability of plants to emerge and allows to create an appropriate environmental place for the plant [17]. It is an essential issue to plant at the appropriate depth to receive good percentage germination, satisfying emergence and high plant population [17]. Emergence of faba beans is hypogeal, meaning that the cotyledons are in the soil while only the shoot emerges from the soil surface $[16,18]$. Therefore, hypogeal germinating plants, compared to epigeal, may be sown both shallower and deeper. are sown deeper. Sowing too shallow can affect poor germination due to unsuitable soil moisture in the top soil layer. Deep placement of seeds in the soil contributes to better rooting of the plant, which decreases lodging susceptibility [19]. Deeper sown plants are able for more efficient use of available soil water. Conversely, the energy needed for emergence is greater for deep-sown compared to shallow-sown seeds [20]. According to Siddique and Loss [18] the recommended faba bean sowing depth is $5-8 \mathrm{~cm}$. Germination starts in 4-12 days after sowing with an optimum temperature around $20^{\circ} \mathrm{C}[13,15]$. According to Baye et al. [17], sowing Faba beans with a depth $8 \mathrm{~cm}$ positively impacted germination and growth, including height, compared to deeper depth of $12 \mathrm{~cm}$.

It was hypothesized that the depth of sowing and density $\left(\mathrm{pcs} \mathrm{m}^{-2}\right)$ as the main factor against the background of the weather conditions would significantly affect plant height, length of vegetative and generative period, as well as yield of seed and straw in faba bean cultivation. It would be assumed that the cultivars of faba bean would differ, taking into account the duration of length of vegetative and generative period and selected traits against different weather course. It is also supposed that the depth of sowing and sowing density would be different for determinate and indeterminate cultivar in different years of experiment.

Information regarding sowing depth and density on the development and yielding of faba bean morphotypes (determinate and indeterminate) is scant. Thus, the objective of the field study was to determine the effect of two sowing depths and three sowing densities on the growth and yielding of Bobas (indeterminate growth habit) and Granit (determinate growth habit) cultivars.

\section{Materials and Methods}

\subsection{Experiment Design and Conditions (Weather, Soil) of Experiment}

A field experiment was established in the field belonging to the Institute of Agroecology and Plant Production of the Wrocław University of Life Sciences in Poland (51 $11^{\prime} \mathrm{N}$, $\left.17^{\circ} 08^{\prime} \mathrm{E}\right)$.

The field experiment was carried out in the years 2011-2013 in a split-plot design. Sowing depth $(5,8 \mathrm{~cm})$ was allocated in the main plots, faba bean cultivars (Bobas- 
indeterminate growth habit, and Granit-determinate growth habit) were placed in the sub-plots and the sowing density $\left(45,60,75 \mathrm{pc} \mathrm{m}^{-2}\right)$ in the sub-sub-plots. The experiment consisted of 12 combinations. Size of the single sub-sub-plot was $15.0 \mathrm{~m}^{2}(10 \mathrm{~m} \times 1.5 \mathrm{~m})$.

Wrockaw and adjacent areas are one of the warmest parts of Lower Silesia in the temperate climate of Poland. In 2011 and 2012, the average temperatures for the vegetation period were higher than the multiannual mean for 1981-2010 and reached 13.7 and $13.8^{\circ} \mathrm{C}$, respectively. In both years, the average monthly temperatures were higher than the multiannual mean. In 2013, March was frosty. That caused the moving of the sowing date to the second half of April. However, other months of the vegetation period were characterized by average temperatures higher than the multiannual mean. The average temperature of the vegetation period in 2013 was $12.2^{\circ} \mathrm{C}$, which was lower than the multiannual mean for the vegetation period by $1.4{ }^{\circ} \mathrm{C}$.

The sum of precipitation during the vegetation period in the years 2011-2013 was changeable. The third year of the experiment was characterized by the highest sum of precipitation $(499 \mathrm{~mm})$, lesser in the first year $(467 \mathrm{~mm})$, and the least in the second year (380 mm). However, these values were higher compared to the multiannual mean sum of precipitation $(314 \mathrm{~mm})$ during the vegetation season.

The experiment was established on typical brown Luvisols developed from light loam underlain by medium loam, suitable for wheat production [21]. Macronutrients availability ( $\mathrm{P}$ and $\mathrm{K}$ - the Egner-Riehm method, $\mathrm{Mg}$-Schachtschabel method) and soil $\mathrm{pH}$ (potentiometrically) in the years of the experiment are presented in Table 1 and are as follows: high to very high $\mathrm{P}$ content, from medium to high $\mathrm{K}$ content, high $\mathrm{Mg}$ content and slightly acidic $\mathrm{pH}$ of soil [22].

Table 1. Soil $\mathrm{pH}$ and abundance in macronutrients $\left(\mathrm{mg} \mathrm{kg}^{-1}\right)$.

\begin{tabular}{ccccc}
\hline Years & pH in 1 M KCl & P & K & Mg \\
\hline 2011 & 5.8 & 74 & 179 & 72 \\
2012 & 6.2 & 73 & 133 & 96 \\
2013 & 5.9 & 62 & 116 & 87 \\
\hline Average (2011-2013) & 6.0 & 70 & 143 & 85 \\
\hline
\end{tabular}

The experimental field was cultivated according to standard plot management techniques and standard agronomic practices. Winter wheat (Triticum aestivum L.) was the preceding crop in each year of the experiment. Directly before faba bean sowing, the soil was cultivated, and fertilization was carried out. Fertilizers were applied in the following doses $\left(\mathrm{kg} \mathrm{ha}^{-1}\right.$ ): $30 \mathrm{~N}$ (ammonium nitrate), $60 \mathrm{P}_{2} \mathrm{O}_{5}$ (triple superphosphate), and $100 \mathrm{~K}_{2} \mathrm{O}$.

The seeds were inoculated with Nitragina (Institute of Soil Science and Plant Cultivation State Research Institute, Puławy, Poland) (an inoculant containing Rhizobium leguminosarum bv. viceae bacteria) directly before sowing. For the experiment, certified seed material has been used with $100 \%$ purity and germination capacity as presented in Table 2 .

Table 2. Characterization of seeds material.

\begin{tabular}{ccccccc}
\hline & \multicolumn{7}{c}{ Cultivars } \\
\cline { 2 - 7 } Specification & $\mathbf{3}$ & Bobas & & Granit \\
& \cline { 2 - 7 } & $\mathbf{2 0 1 1}$ & $\mathbf{2 0 1 3}$ & $\mathbf{2 0 1 1}$ & $\mathbf{2 0 1 2}$ & $\mathbf{2 0 1 3}$ \\
\hline Germination capacity (\%) & 95 & 98 & 94 & 80 & 94 & 80 \\
Purity (\%) & 100 & 100 & 100 & 100 & 100 & 100 \\
Mass of 1000 seeds (g) & 500 & 667 & 612 & 466 & 510 & 554 \\
\hline
\end{tabular}

Sowing and harvesting dates in the years of research and plant protection treatment are presented in Table 3. Plant protection was carried out in accordance with the assumptions of integrated pest management. 
Table 3. Sowing and harvesting date and plant protection of faba bean in years 2011-2013.

\begin{tabular}{|c|c|c|c|c|}
\hline \multirow{2}{*}{\multicolumn{2}{|c|}{ Specification }} & \multicolumn{3}{|c|}{ Years } \\
\hline & & 2011 & 2012 & 2013 \\
\hline \multicolumn{2}{|c|}{ Sowing Date } & $31 / 03$ & $26 / 03$ & $16 / 04$ \\
\hline Plant Protection Products & Active Substances & & & \\
\hline Linurex 500 SC- $1.5 \mathrm{dm}^{3} \mathrm{ha}^{-1}$ & Linuron & $02 / 04$ & $26 / 03$ & $17 / 04$ \\
\hline Basagran 480 SL-2 $\mathrm{dm}^{3} \mathrm{ha}^{-1}$ & Bentazone & $02 / 05$ & $07 / 05$ & $10 / 05$ \\
\hline Alert $375-1.3 \mathrm{dm}^{3} \mathrm{ha}^{-1}$ & Flusilazole and carbendazim & $19 / 05$ & $18 / 06$ & - \\
\hline Karate Zeon 050 SC- $0.1 \mathrm{dm}^{3} \mathrm{ha}^{-1}$ & Lambda-cyhalothrin & - & $29 / 05$ & - \\
\hline Bi 58 Nowy 400 EC- $0.5 \mathrm{dm}^{3} \mathrm{ha}^{-1}$ & Dimethoate & - & $22 / 05$ & $22 / 05$ \\
\hline Mospilan $20 \mathrm{SP}-1 \mathrm{dm}^{3} \mathrm{ha}^{-1}$ & Acetamipride & - & $31 / 05$ & - \\
\hline Fastac $0.1 \mathrm{dm}^{3} \mathrm{ha}^{-1}$ & Alpha-cypermethrin & $22 / 06$ & $18 / 06$ & - \\
\hline \multicolumn{2}{|c|}{ Harvesting date } & $11 / 08$ & $16 / 08$ & $14 / 08$ \\
\hline
\end{tabular}

\subsection{Measurements}

The field observations were done each year of the study during the vegetation period of faba bean plants. Growing stages in $\mathrm{BBCH}$ scale and the development of plants were noted [23]. Before harvest, plant density was determined at 2 RMT (running metres) of the middle row and then the results were converted to $1 \mathrm{~m}^{-2}$. The plant height to the top of the main shoot $(\mathrm{cm})$ was measured on 10 randomly selected plants from each plot before harvest. After harvest, the yield of seeds and straw from each sub-sub-plot was determined $\left(\mathrm{t} \mathrm{ha}{ }^{-1}\right.$ ) at moisture level at $15 \%$. The moisture of faba bean seeds has been converted to a constant moisture content using the following formula:

$$
\mathrm{x}=\mathrm{P} \cdot \frac{100-\mathrm{W} 1}{100-\mathrm{W} 2}
$$

$\mathrm{x}$-yield after being converted to the assumed moisture content $\left(\mathrm{t} \mathrm{ha}{ }^{-1}\right)$

$\mathrm{P}$ - yield $\left(\mathrm{t} \mathrm{ha}{ }^{-1}\right)$

W1—seed moisture at harvest (\%)

W2—seed moisture content determined, assumed (\%)

\subsection{Statistical Analyses}

The analysis of variance (ANOVA) was done at the significance level $p<0.05$ using Statistica program 13.1 (StatSoft, Kraków, Poland). The experiment included four factors: two sowing depths, two cultivars, three sowing densities, three years, and four randomized replicates arranged in a split-plot design. For the resulting data (plant development) presented in the Table 4, standard deviations (SD) were calculated. Homogeneous groups were determined by Tukey's multiple range test using consecutive letters starting from " $a$ " - the most beneficial value- to " $\mathrm{f}$ "- the least beneficial in terms of analysed traits. Figures were prepared in Excel 2010.

Table 4. Effect of weather conditions on faba bean development stages in the years 2011-2013.

\begin{tabular}{|c|c|c|c|c|c|c|c|c|c|}
\hline \multirow{3}{*}{ Specification } & \multicolumn{9}{|c|}{ Development Stages } \\
\hline & \multicolumn{2}{|c|}{$\begin{array}{c}\text { Vegetative } \\
\text { (V) }\end{array}$} & \multirow{2}{*}{$\begin{array}{c}\text { Average for } \\
\text { Years }\end{array}$} & \multicolumn{2}{|c|}{$\begin{array}{c}\text { Generative } \\
\text { (G) }\end{array}$} & \multirow{2}{*}{$\begin{array}{c}\text { Average for } \\
\text { Years }\end{array}$} & \multicolumn{2}{|c|}{$\begin{array}{c}\text { Vegetation } \\
\text { Period }(V+G)\end{array}$} & \multirow{2}{*}{$\begin{array}{c}\text { Average for } \\
\text { Years }\end{array}$} \\
\hline & Bobas & Granit & & Bobas & Granit & & Bobas & Granit & \\
\hline \multicolumn{10}{|c|}{2011} \\
\hline Length of stages [days] & 46.0 & 46.0 & $46.0 \pm 0.0$ & 86 & 81 & $83.5 \pm 3.5$ & 132 & 127 & $130 \pm 3.5$ \\
\hline Average temperature $\left[{ }^{\circ} \mathrm{C}\right]$ & 12.0 & 12.0 & 12.0 & 18.7 & 18.6 & 18.7 & 16.4 & 16.2 & 16.4 \\
\hline Total sum of precipitation [mm] & 61.5 & 61.5 & 61.05 & 296.0 & 284.8 & 290.4 & 357.5 & 346.3 & 351.9 \\
\hline
\end{tabular}


Table 4. Cont.

\begin{tabular}{|c|c|c|c|c|c|c|c|c|c|}
\hline \multirow{3}{*}{ Specification } & \multicolumn{9}{|c|}{ Development Stages } \\
\hline & \multicolumn{2}{|c|}{$\begin{array}{l}\text { Vegetative } \\
\text { (V) }\end{array}$} & \multirow{2}{*}{$\begin{array}{l}\text { Average for } \\
\text { Years }\end{array}$} & \multicolumn{2}{|c|}{$\begin{array}{c}\text { Generative } \\
\text { (G) }\end{array}$} & \multirow{2}{*}{$\begin{array}{l}\text { Average for } \\
\text { Years }\end{array}$} & \multicolumn{2}{|c|}{$\begin{array}{c}\text { Vegetation } \\
\text { Period }(V+G)\end{array}$} & \multirow{2}{*}{$\begin{array}{l}\text { Average for } \\
\text { Years }\end{array}$} \\
\hline & Bobas & Granit & & Bobas & Granit & & Bobas & Granit & \\
\hline \multicolumn{10}{|c|}{2012} \\
\hline Length of stages [days] & 45 & 45 & $45 \pm 0.0$ & 96 & 91 & $93.5 \pm 3.5$ & 141 & 136 & $138.5 \pm 3.5$ \\
\hline Average temperature $\left[{ }^{\circ} \mathrm{C}\right]$ & 10.7 & 10.7 & 10.7 & 18.1 & 18.2 & 18.2 & 15.7 & 15.8 & 15.8 \\
\hline Total sum of precipitation [mm] & 111.8 & 111.8 & 111.8 & 202.6 & 239.3 & 220.9 & 314.4 & 351.1 & 332.75 \\
\hline \multicolumn{10}{|c|}{2013} \\
\hline Length of stages [days] & 39 & 39 & $39 \pm 0.0$ & 77 & 75 & $76 \pm 1.4$ & 116 & 114 & $115 \pm 1.4$ \\
\hline Average temperature $\left[{ }^{\circ} \mathrm{C}\right]$ & 14.6 & 14.6 & 14.6 & 19.1 & 18.6 & 18.6 & 17.6 & 17.2 & 17.4 \\
\hline Total sum of precipitation [mm] & 116.4 & 116.4 & 116.4 & 302.5 & 280.9 & 291.7 & 418.9 & 397.3 & 408.1 \\
\hline \multicolumn{10}{|c|}{ Average for the years 2011-2013 } \\
\hline $\begin{array}{l}\text { Length of stages [days] } \\
\text { (average for cultivars) }\end{array}$ & $\begin{array}{c}43 \pm \\
3.8\end{array}$ & $\begin{array}{c}43 \pm \\
3.8\end{array}$ & $43 \pm 0.0$ & $\begin{array}{c}86 \pm \\
9.5\end{array}$ & $\begin{array}{c}82 \pm \\
8.1\end{array}$ & $84 \pm 13.3$ & $\begin{array}{c}130 \pm \\
12.7\end{array}$ & $\begin{array}{c}126 \pm \\
11.1\end{array}$ & $128.0 \pm 11.9$ \\
\hline Average temperature $\left[{ }^{\circ} \mathrm{C}\right]$ & 12.3 & 12.3 & 12.3 & 18.6 & 18.5 & 18.6 & 16.5 & 16.4 & 16.5 \\
\hline Total sum of precipitation [mm] & 96.6 & 96.6 & 96.6 & 267.0 & 268.3 & 267.6 & 363.6 & 364.9 & 364.3 \\
\hline
\end{tabular}

\pm means SD for average for length of stages in the years of research.

\section{Results}

\subsection{Effect of Weather Conditions in Years of Research on the Plant Development of Faba Bean}

The greatest precipitation before sowing was noted in the first year of the experiment, less in 2013 and the least in 2012. In the same year, the least amount rainfall was found in the flowering stage. The most favourable precipitation during harvest (II decade of August was stated in the second year of field study (Figures 1-3). Faba bean sowing in 2011-2012 was performed in the third decade of March in a range of minimum $\left(0-4{ }^{\circ} \mathrm{C}\right)$ and maximum $\left(13-14{ }^{\circ} \mathrm{C}\right.$ ) temperature (Figures 1 and 2). In 2013 there was observed low temperature in third decade of March. Sowing faba bean in this year was conducted in the second decade of April at a minimum temperature about $6^{\circ} \mathrm{C}$ and maximum of about $17^{\circ} \mathrm{C}$ (Figure 3).

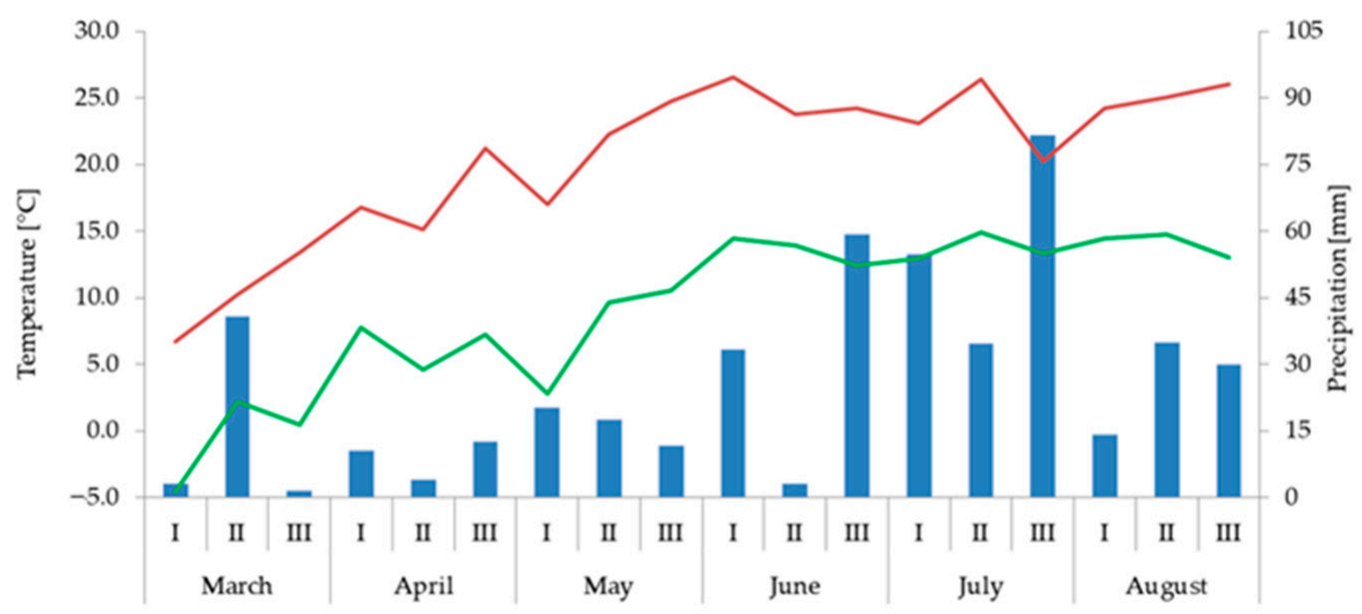

Total sum of precipitation $[\mathrm{mm}]$-Average minimum temperature $\left[{ }^{\circ} \mathrm{C}\right]$ —Average maximum temperature $\left[{ }^{\circ} \mathrm{C}\right]$

Figure 1. Decade weather condition in 2011 with marking minimum and maximum temperature. 


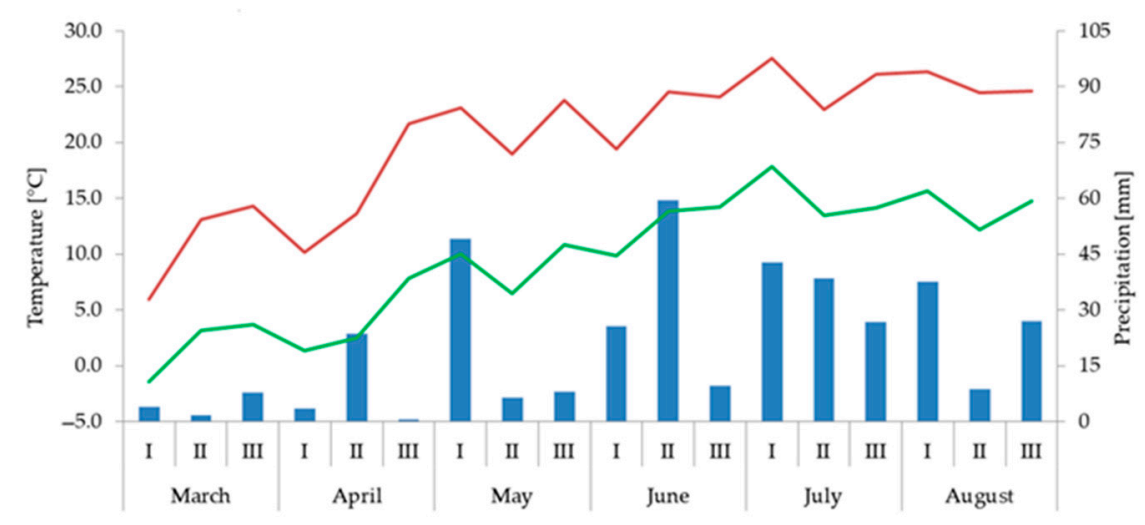

Total sum of precipitation $[\mathrm{mm}]$ —Average minimum temperature $\left[{ }^{\circ} \mathrm{C}\right]$ —Average maximum temperature $\left[{ }^{\circ} \mathrm{C}\right]$

Figure 2. Decade weather condition in 2012 with marking minimum and maximum temperature.

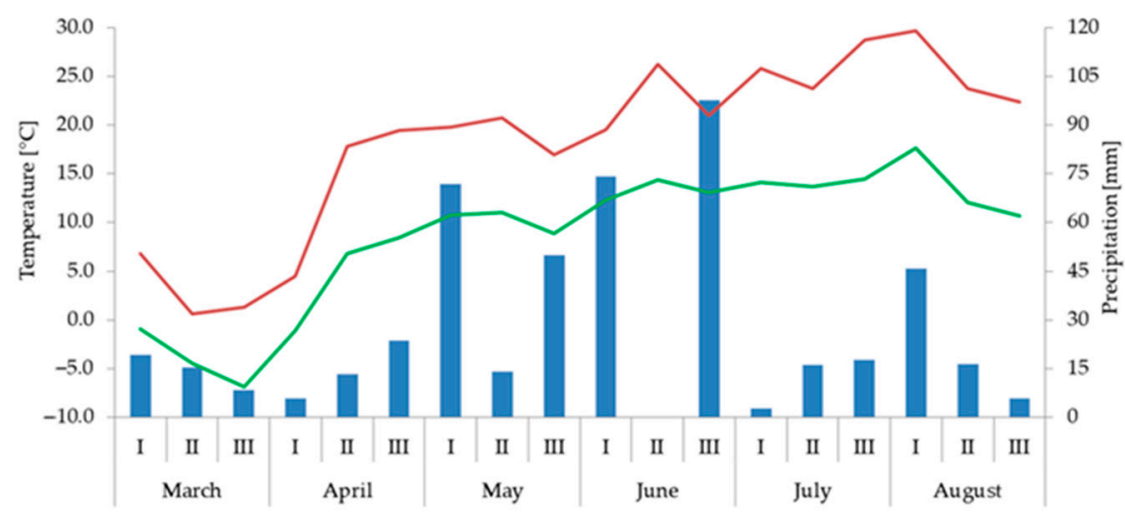

Total sum of precipitation $[\mathrm{mm}]$ —Average minimum temperature $\left[{ }^{\circ} \mathrm{C}\right]$ - Average maximum temperature $\left[{ }^{\circ} \mathrm{C}\right]$

Figure 3. Decade weather condition in 2013 marking minimum and maximum temperature and precipitation in decades.

Table 4 presents the average temperature and total sum of precipitation for the vegetative and generative period for determinate and indeterminate cultivar. On the basis of field observations, it was stated that the sowing depth, density and repetitions did not differentiate the duration of development stages. The length of the development period of faba beans in the experiment varied, on average, from 126 days for Granit cultivar to 130 days for Bobas cultivar. Greater differences in the length of vegetation period was stated in Bobas cultivar $(\mathrm{SD} \pm 12.7)$ than Granit cultivar $(\mathrm{SD} \pm 11.1)$. Bobas indeterminate cultivar characterized by longer vegetation period $(V+G)$ compared to Granit determinate cultivar in the years 2011-2013. The length of vegetative development $(\mathrm{V})$ in both cultivars in the years of experiment did not vary and lasted about 43 days. Differences in the number of days were found in the generative development of both cultivars. In the years of experiment, a longer generative development $(\mathrm{G})$ concerned Bobas indeterminate cultivar (Table 4). The average temperature in the years of the experiment ranged from $12.3^{\circ} \mathrm{C}$ (2011) to $18.6^{\circ} \mathrm{C}$ (2012). Differences were observed in the total sum of precipitation. The longest vegetation period was found in 2012 and the shortest in 2013. The least differences in the length of vegetation period concerned the third year of experiment $(\mathrm{SD} \pm 1.4)$.

\subsection{Effect of Examined Factors on Plant Density, Height of Plants before Harvest and Seed and Straw Yield}

Sowing depth played an important role in plant density in 2011 and 2013, while in turn, cultivar only in 2011 and 2012. Plant density before harvest $\left(\mathrm{pc} \mathrm{m}^{-2}\right)$ in the years experiment was significantly dependent on sowing density. A significant effect was also found for the interaction: sowing depth $(\mathrm{SDH}) \times$ sowing density (SDY) and (cultivar) $\mathrm{C} \times$ 
(sowing density) SDY in the first year of experiment. Sowing depth influenced on plant height in 2011 and 2013 while cultivar differentiated significantly this trait in all years of experiment (Table 5). Sowing density only had a significant effect on plant height in 2013. In turn, interaction SDH $\times$ SDY and C $\times$ SDY affected significantly this trait in 2011 (Table 5).

Table 5. Effect of examined factors on plant density and height of plants before harvest.

\begin{tabular}{|c|c|c|c|c|c|c|}
\hline \multirow{3}{*}{ Specification } & \multicolumn{3}{|c|}{$\begin{array}{l}\text { Plant Density before Harvest } \\
{\left[\mathrm{pc} \mathrm{m}^{-2}\right]}\end{array}$} & \multicolumn{3}{|c|}{$\begin{array}{l}\text { Height of Plants } \\
{[\mathrm{cm}]}\end{array}$} \\
\hline & \multicolumn{6}{|c|}{$p$-Value } \\
\hline & 2011 & 2012 & 2013 & 2011 & 2012 & 2013 \\
\hline \multicolumn{7}{|c|}{ For factors } \\
\hline Sowing depth (SDH) & 0.0008 & 0.1645 & 0.0198 & 0.0034 & 0.4845 & 0.0007 \\
\hline Cultivar (C) & 0.0071 & 0.0114 & 0.9628 & 0.0000 & 0.0000 & 0.0000 \\
\hline Sowing density (SDY) & 0.0000 & 0.0000 & 0.0000 & 0.2818 & 0.8549 & 0.0193 \\
\hline \multicolumn{7}{|c|}{ For interactions } \\
\hline $\mathrm{SDH} \times \mathrm{C}$ & 0.4175 & 0.9257 & 0.8889 & 0.4816 & 0.0726 & 0.2453 \\
\hline $\mathrm{SDH} \times \mathrm{SDY}$ & 0.0013 & 0.7486 & 0.8163 & 0.0004 & 0.5208 & 0.9371 \\
\hline $\mathrm{C} \times \mathrm{SDY}$ & 0.0002 & 0.6047 & 0.9254 & 0.0000 & 0.8127 & 0.6391 \\
\hline
\end{tabular}

Sowing depth had a significant effect on seed yield in 2011 and 2013. Cultivar and sowing density played a pivotal role in seed yield shaping in all years of the experiment. There were found also interaction: sowing depth $(\mathrm{SDH}) \times$ cultivar $(\mathrm{C})$ and $\mathrm{C} \times \mathrm{SDY}$ in 2011, 2013, SDH $\times$ SDY in 2013 (Table 6).

Table 6. Effect of examined factors on the seed and straw yield of faba bean $\left[t \mathrm{th}^{-1}\right]$.

\begin{tabular}{ccccccc}
\hline & \multicolumn{7}{c}{ Yield [t ha ${ }^{-1}$ ] } \\
\cline { 2 - 7 } Specification & \multicolumn{7}{c}{ Seed } & \multicolumn{7}{c}{ Straw } \\
\cline { 2 - 7 } & $\mathbf{7}$-Value \\
\cline { 2 - 7 } & $\mathbf{2 0 1 1}$ & $\mathbf{2 0 1 2}$ & $\mathbf{2 0 1 3}$ & $\mathbf{2 0 1 1}$ & $\mathbf{2 0 1 2}$ & $\mathbf{2 0 1 3}$ \\
\hline \multicolumn{7}{c}{ For factors } \\
\hline Sowing depth (SDH) & 0.0020 & 0.1885 & 0.0010 & 0.2841 & 0.1387 & 0.0184 \\
Cultivar (C) & 0.0000 & 0.0001 & 0.0001 & 0.0857 & 0.0001 & 0.1140 \\
Sowing density (SDY) & 0.0000 & 0.0189 & 0.0000 & 0.0000 & 0.0594 & 0.0000 \\
\hline & \multicolumn{7}{c}{ For interactions } \\
\hline SDH $\times$ C C & 0.0133 & 0.5922 & 0.0255 & 0.3563 & 0.2893 & 0.0285 \\
SDH $\times$ SDY & 0.0580 & 0.6407 & 0.0000 & 0.0547 & 0.3123 & 0.0133 \\
C $\times$ SDY & 0.0114 & 0.8561 & 0.0005 & 0.0050 & 0.9779 & 0.8071 \\
\hline
\end{tabular}

Sowing depth significantly affected plant density in 2011 and 2013. In these years of research, opposite results were obtained: a higher planting density at $5 \mathrm{~cm}$ in 2011 $\left(48.7 \mathrm{pcs} \mathrm{m}^{2}\right)$ and in 2013 at $8 \mathrm{~cm}\left(53.4 \mathrm{pcs} \mathrm{m}^{2}\right)$. Cultivar had no effect on plant density in all years of experiment. Sowing density affected significantly on plant density in all years of experiment. Plant density values were much higher when using 75 seeds per $\mathrm{m}^{2}$ in all years of the experiment, while the lowest used 45 seeds per $\mathrm{m}^{2}$ (Table 7).

Significantly higher plants were found in 2011 and 2013 at $8 \mathrm{~cm}$ sowing depth $(65.5 \mathrm{~cm}$ and 90.5, respectively). A different reaction in a case of cultivar was found for plant height. In all years of the experiment, higher plants were stated in Bobas cultivar $(7.3,38.3 \mathrm{~cm})$ higher than Granit (Table 7). 
Table 7. Table Effect of examined factors on plant density, height and seed and straw yield.

\begin{tabular}{|c|c|c|c|c|c|}
\hline \multicolumn{2}{|c|}{ Specification } & $\begin{array}{l}\text { Plant Density before Harvest } \\
{\left[\mathrm{pc} \mathrm{m}^{-2}\right]}\end{array}$ & \multirow[t]{2}{*}{$\begin{array}{l}\text { Plant Height } \\
{[\mathrm{cm}]}\end{array}$} & \multirow[t]{2}{*}{$\begin{array}{l}\text { Seed Yield } \\
{\left[\mathrm{t} \mathrm{ha}^{-1}\right]}\end{array}$} & \multirow[t]{2}{*}{$\begin{array}{c}\text { Straw Yield } \\
{\left[\mathrm{t} \mathrm{ha}^{-1}\right]}\end{array}$} \\
\hline \multicolumn{3}{|c|}{2011} & & & \\
\hline \multirow{2}{*}{$\begin{array}{l}\text { Sowing depth } \\
\quad(\mathrm{SDH})\end{array}$} & 5 & $48.7 \mathrm{a}$ & $62.5 \mathrm{~b}$ & $4.50 \mathrm{a}$ & $3.26 a$ \\
\hline & 8 & $44.8 \mathrm{~b}$ & $65.5 a$ & $4.26 \mathrm{~b}$ & $3.18 \mathrm{a}$ \\
\hline \multirow{2}{*}{ Cultivars (C) } & Bobas & $47.7 \mathrm{a}$ & $67.5 \mathrm{a}$ & $4.75 \mathrm{a}$ & $3.51 \mathrm{a}$ \\
\hline & Granit & $45.8 \mathrm{a}$ & $60.5 b$ & $4.01 \mathrm{~b}$ & $2.93 b$ \\
\hline \multirow{3}{*}{$\begin{array}{l}\text { Sowing density } \\
\quad \text { (SDY) }\end{array}$} & 45 & $37.5 c$ & $64.5 \mathrm{a}$ & $4.18 \mathrm{a}$ & $3.00 \mathrm{a}$ \\
\hline & 60 & $48.3 b$ & $63.9 a$ & $4.42 \mathrm{a}$ & $3.23 \mathrm{ab}$ \\
\hline & 75 & $54.5 \mathrm{a}$ & $63.6 a$ & $4.55 \mathrm{a}$ & $3.38 \mathrm{~b}$ \\
\hline \multicolumn{6}{|c|}{2012} \\
\hline \multirow{2}{*}{$\begin{array}{l}\text { Sowing depth } \\
\quad(\mathrm{SDH})\end{array}$} & 5 & $49.6 a$ & $69.8 \mathrm{a}$ & $6.62 a$ & $4.22 \mathrm{a}$ \\
\hline & 8 & $51.1 \mathrm{a}$ & $68.5 a$ & $6.25 b$ & $3.89 \mathrm{a}$ \\
\hline \multirow{2}{*}{ Cultivars (C) } & Bobas & $51.8 \mathrm{a}$ & $88.0 \mathrm{a}$ & $7.27 \mathrm{a}$ & $4.88 \mathrm{a}$ \\
\hline & Granit & $48.8 \mathrm{a}$ & $50.3 b$ & $5.60 \mathrm{~b}$ & $3.23 b$ \\
\hline \multirow{3}{*}{$\begin{array}{l}\text { Sowing density } \\
\text { (SDY) }\end{array}$} & 45 & $38.8 \mathrm{c}$ & $68.5 a$ & $6.20 \mathrm{a}$ & $3.91 \mathrm{a}$ \\
\hline & 60 & $50.2 b$ & $69.7 a$ & $6.39 a$ & $3.81 \mathrm{a}$ \\
\hline & 75 & $61.9 \mathrm{a}$ & $69.4 a$ & $6.72 \mathrm{a}$ & $4.44 a$ \\
\hline \multicolumn{6}{|c|}{2013} \\
\hline \multirow{2}{*}{$\begin{array}{l}\text { Sowing depth } \\
\quad(\mathrm{SDH})\end{array}$} & 5 & $48.4 \mathrm{~b}$ & $81.3 b$ & $3.32 b$ & $1.89 \mathrm{~b}$ \\
\hline & 8 & $53.4 \mathrm{a}$ & $90.5 a$ & $3.53 a$ & $2.42 \mathrm{a}$ \\
\hline \multirow{2}{*}{ Cultivars (C) } & Bobas & $51.0 \mathrm{a}$ & $90.3 a$ & $3.61 \mathrm{a}$ & $2.12 \mathrm{a}$ \\
\hline & Granit & $50.9 a$ & $81.5 b$ & $3.24 b$ & $2.19 a$ \\
\hline \multirow{3}{*}{$\begin{array}{l}\text { Sowing density } \\
\text { (SDY) }\end{array}$} & 45 & $39.6 c$ & $83.7 \mathrm{a}$ & $3.24 \mathrm{a}$ & $1.92 \mathrm{a}$ \\
\hline & 60 & $51.5 b$ & $85.7 \mathrm{a}$ & $3.50 \mathrm{~b}$ & $2.17 \mathrm{ab}$ \\
\hline & 75 & $61.8 \mathrm{a}$ & $88.4 \mathrm{a}$ & $3.54 b$ & $2.38 \mathrm{~b}$ \\
\hline
\end{tabular}

Means for factors and years. Different letters indicate significant differences between factors (Tukey's multiple range test).

Seed yield was dependent on sowing depth in all years of experiment. In the first two years of the experiment, a significantly higher seed yield was stated at $5 \mathrm{~cm}$ sowing depth (4.50 and $6.62 \mathrm{t} \mathrm{ha}^{-1}$ respectively), while in 2013, a significantly higher value at $8 \mathrm{~cm}$ of depth (3.53 ha $\left.{ }^{-1}\right)$ was observed. Higher seed yield was observed in 2012, while the lowest was in 2013. Seed yield also depended on cultivar. Bobas indeterminate cultivar characterized by higher seed yield in all years of experiment. Increase sowing rate to 60 seeds per $\mathrm{m} 2$ resulted in larger seed yield only in the last year of experiment (Table 7).

The results of the analysis of sowing depth effect showed that deeper sowing in 2013 led to greater straw yield. Cultivar with indeterminate growth type characterized by larger straw yield in two first years of research. In turn, enlargement seed sown per $\mathrm{m}^{2}$ contributed to increase straw yield in 2011 and 2013 (Table 7).

Higher plant density was noted by $5 \mathrm{~cm}$ of sowing depth using 60 and 75 seeds on $\mathrm{m}^{2}$ in 2011. Increasing tendency of plant density per $1 \mathrm{~m}^{2}$ both at 5 and $8 \mathrm{~cm}$ depth was stated. The greatest plant density was found using 75 seeds per $\mathrm{m}^{2}$, while the lowest with 45 seeds per $\mathrm{m}^{2}$ (Figure 4 ).

Higher plant density was stated in Bobas cultivar using 75 seeds on $1 \mathrm{~m}^{2}$, while Granit characterized by greater plant density using 60 seeds sown per $\mathrm{m}^{2}$ (Figure 5). Change of seed sowing from 45 to 75 seeds per $\mathrm{m}^{2}$ in both cultivars caused an increase in plant density before harvest (Figure 5).

Indeed, higher plants were observed at $8 \mathrm{~cm}$ sowing depth using only 60 seeds per $\mathrm{m}^{2}$ and lower using the same amount of seeds at $5 \mathrm{~cm}$ of sowing depth (Figure 6). 


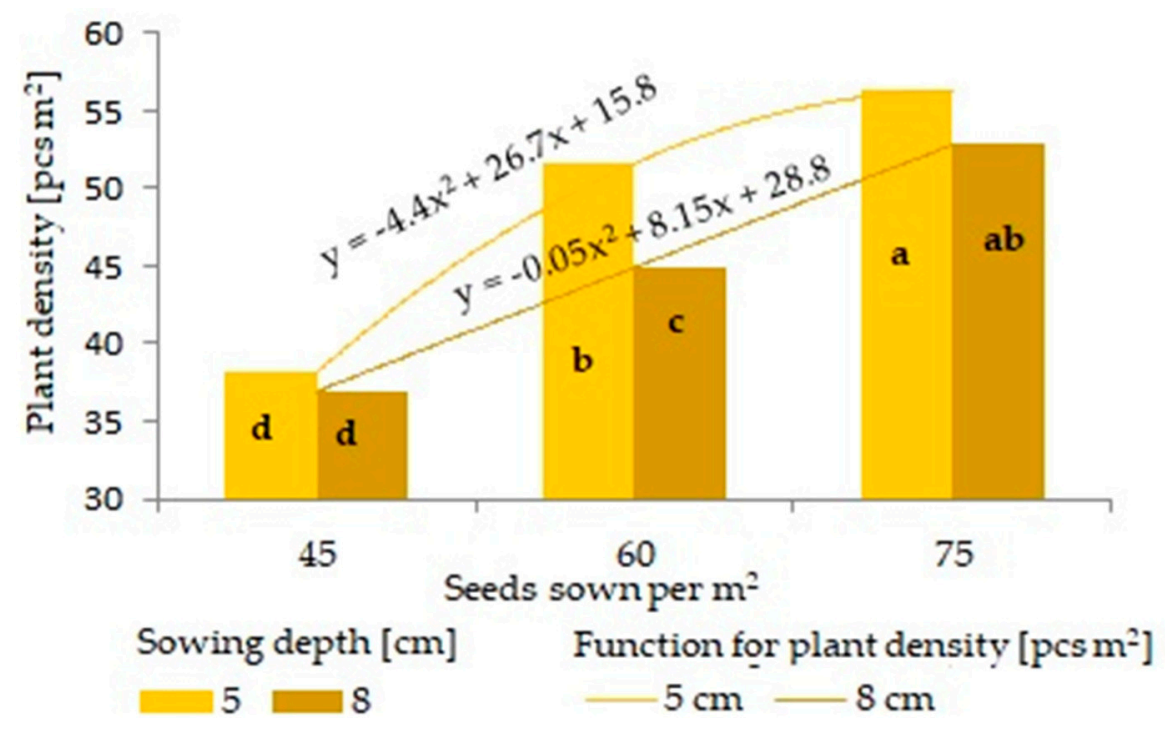

Figure 4. Plant density before harvest in 2011 (interaction SDH $\times$ SDY). Different letters indicate significant differences between factors (Tukey's multiple range test).

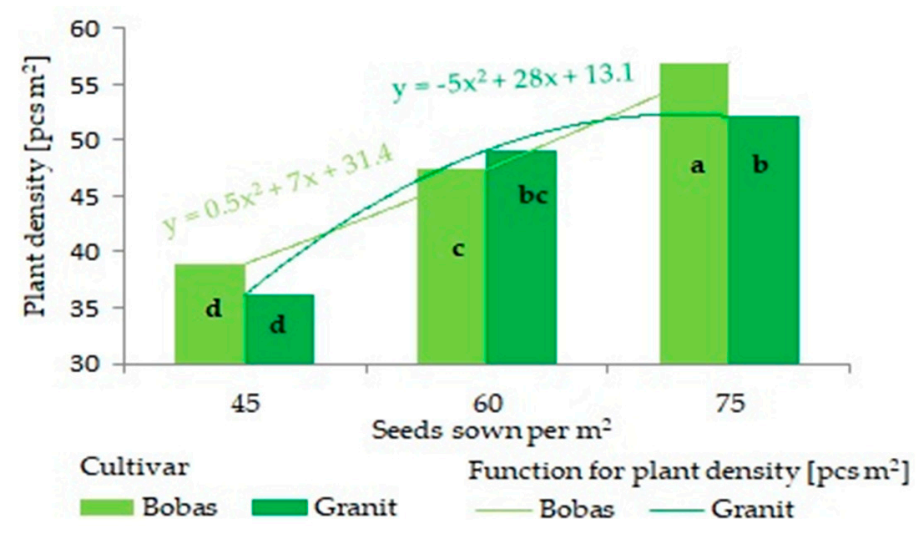

Figure 5. Plant density before harvest in $2011(\mathrm{C} \times \mathrm{SDY})$. Different letters indicate significant differences between factors (Tukey's multiple range test).

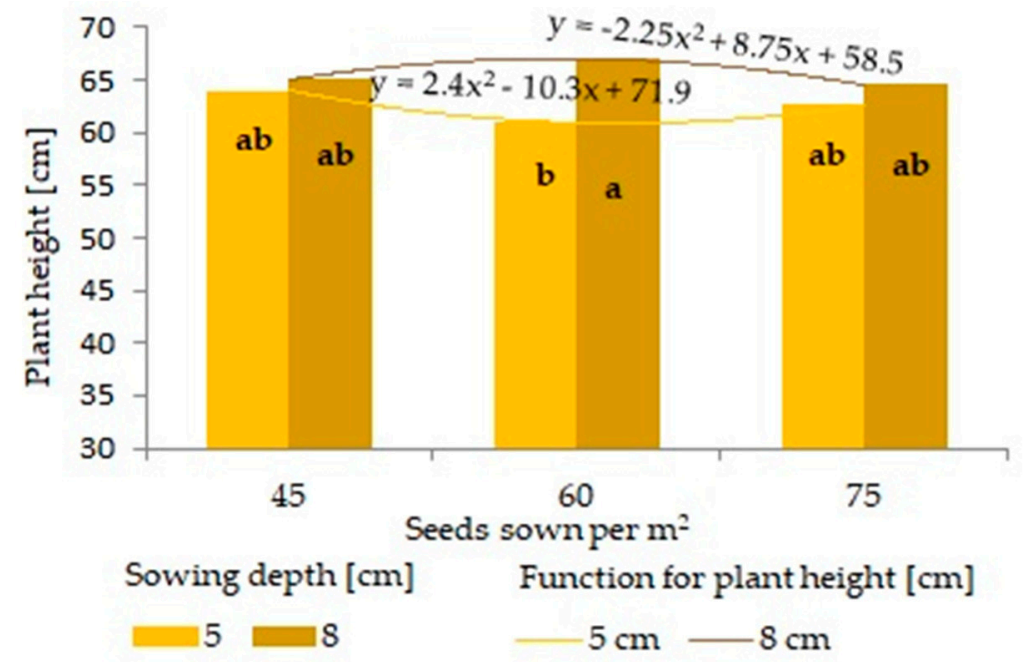

Figure 6. Plant height in $2011(\mathrm{SDH} \times \mathrm{SDY})$. Different letters indicate significant differences between factors (Tukey's multiple range test). 
Bobas indeterminate cultivar were characterized by higher plants using all sowing rates. The highest plants were observed in Bobas using 45 seeds per $\mathrm{m}^{2}$, while the lowest were seen in Granit cultivar using the same number of seeds per $\mathrm{m}^{2}$ (Figure 7).

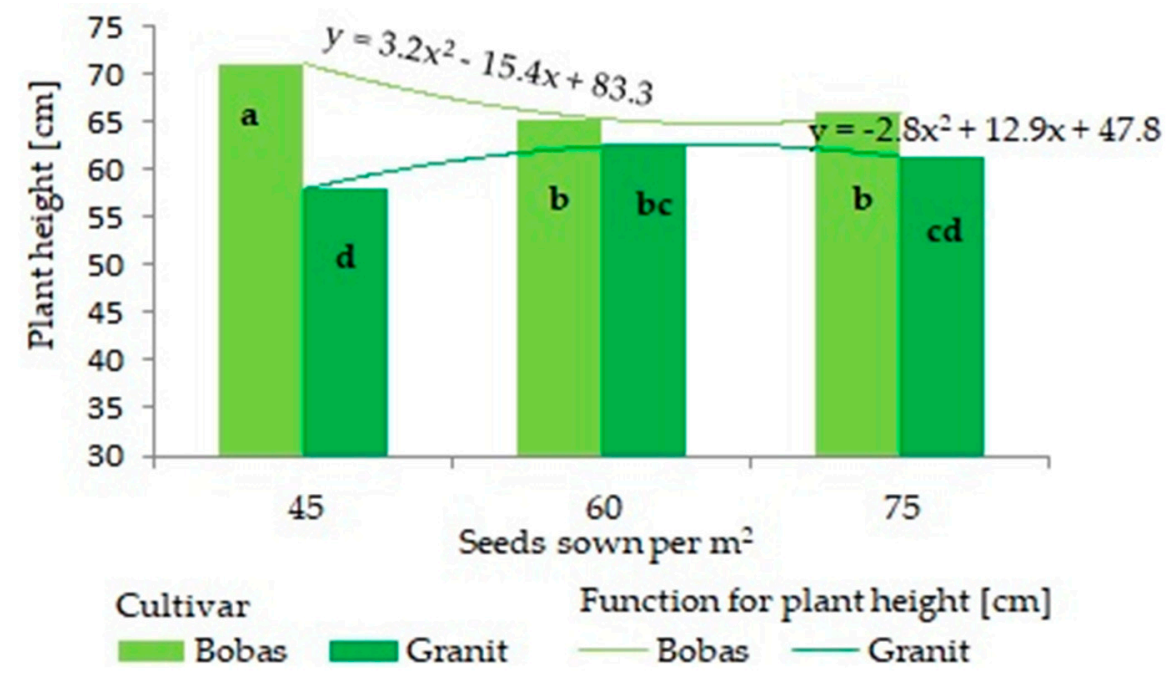

Figure 7. Plant height in 2011 (C $\times$ SDY). Different letters indicate significant differences between factors (Tukey's multiple range test).

In the years 2011-2013, independently sowing depth in indeterminate morphotypes of faba bean yielded higher compared to determinate type of growth. Decrease of sowing depth in Bobas, contradictory to Granit, resulted in increased seed yield in 2011. In 2013, a sowing depth of $8 \mathrm{~cm}$ enhanced Granit productivity (Figure 8).

\section{1}

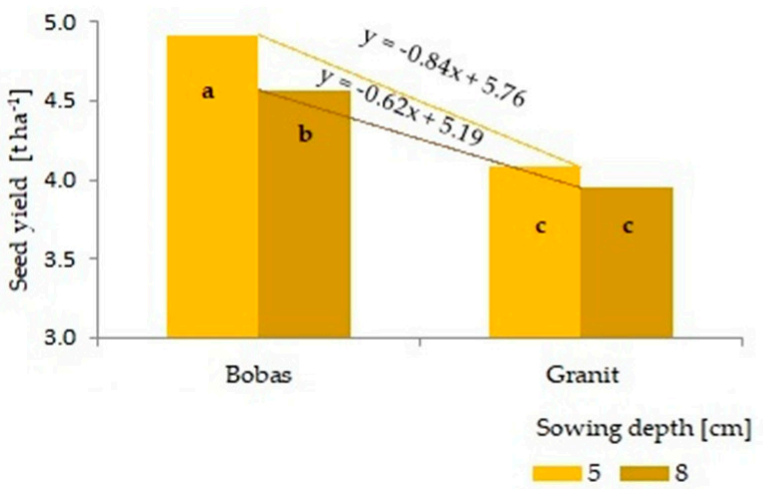

2013

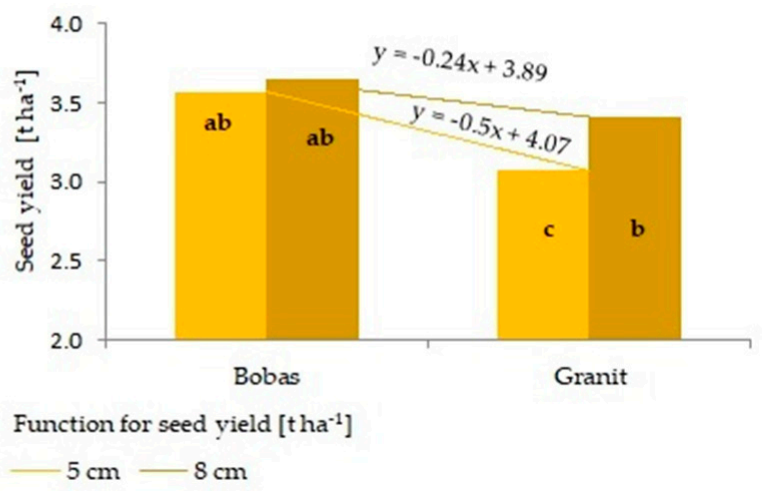

Figure 8. Seed yield in 2011and $2013(\mathrm{SDH} \times \mathrm{C}$ ). Different letters indicate significant differences between factors (Tukey's multiple range test).

Deeper sowing using 45 seeds per $\mathrm{m}^{2}$ enhanced led to an increase of seed yield. Change the sowing rate from 45 to 60 pcs per $\mathrm{m}^{2}$ caused also higher faba bean productivity (Figure 9).

Bobas cultivar had the greater than Granit seed yield using all sowing rates in 2011 and 2013. Determinate cultivar increase yield when changing the sowing rate from 45 to $60 \mathrm{pcs} \mathrm{m}^{2}$ in these years. The most beneficial sowing rate in Bobas cultivation for seeds in 2013 was 75 pcs $\mathrm{m}^{2}$. However, in 2011 seed yield obtained from indeterminate morphotype did not vary significantly between tested sowing densities. (Figure 10). 


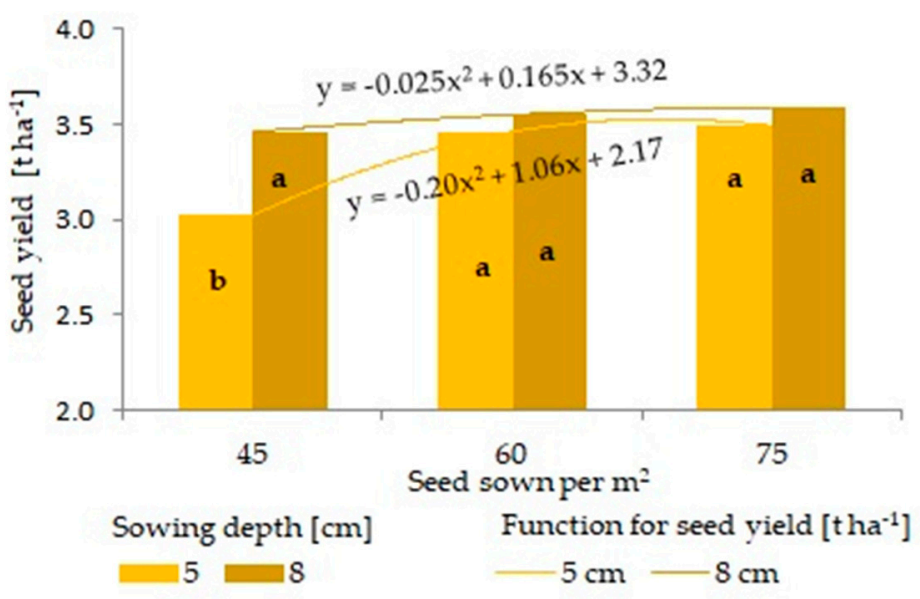

Figure 9. Seed yield in $2011(\mathrm{SDH} \times \mathrm{SDY})$. Different letters indicate significant differences between factors (Tukey's multiple range test).

2011

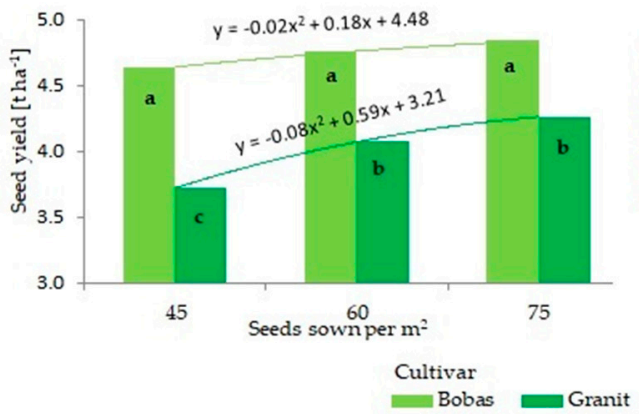

2013

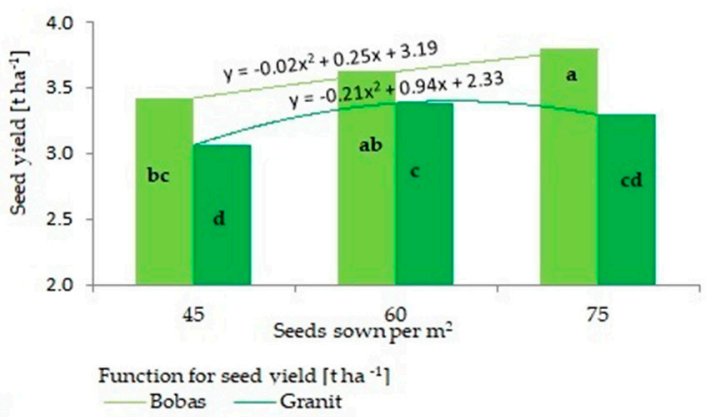

Figure 10. Seed yield in 2011 and 2013 (C × SDH). Different letters indicate significant differences between factors (Tukey's multiple range test).

The greatest straw yield was stated in Bobas cultivar in all range of sowing rate, compared to Granit (Figure 11). The least straw yield was found in determinate morphotype using 45 seeds per $\mathrm{m}^{2}$ (Figure 11).

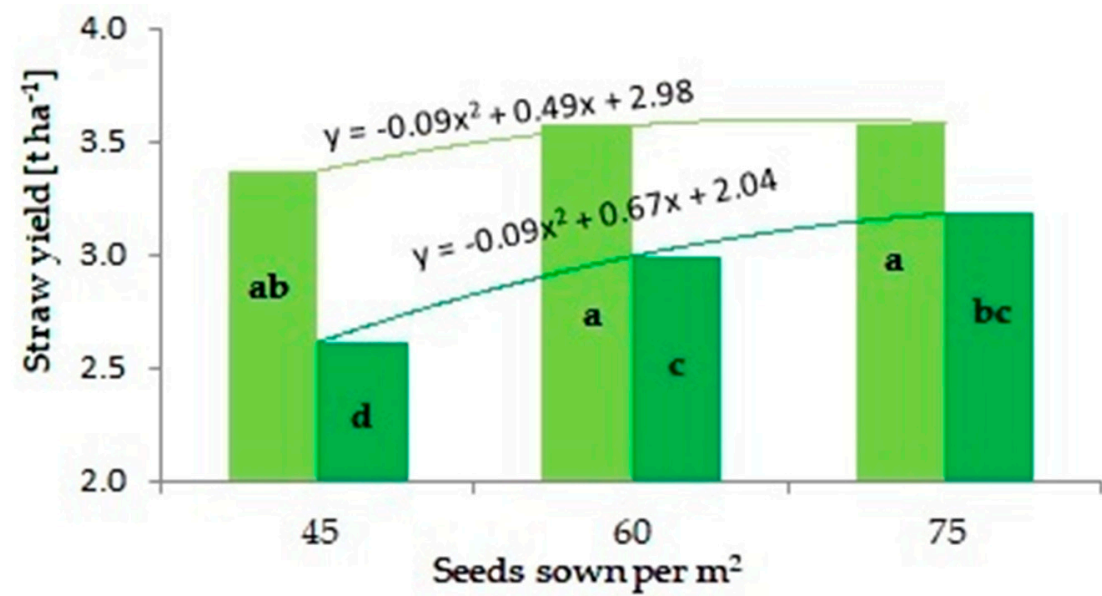

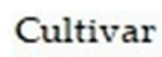

Bobas
Function for straw yield [ $\mathrm{tha}^{-1}$ ]

Bobas

Granit

Figure 11. Straw yield in 2011(C $\times$ SDY). Different letters indicate significant differences between factors (Tukey's multiple range test). 
Tested cultivars did not differently affect straw yield. This trait in both cultivars was significantly higher on deeper sowing (Figure 12).

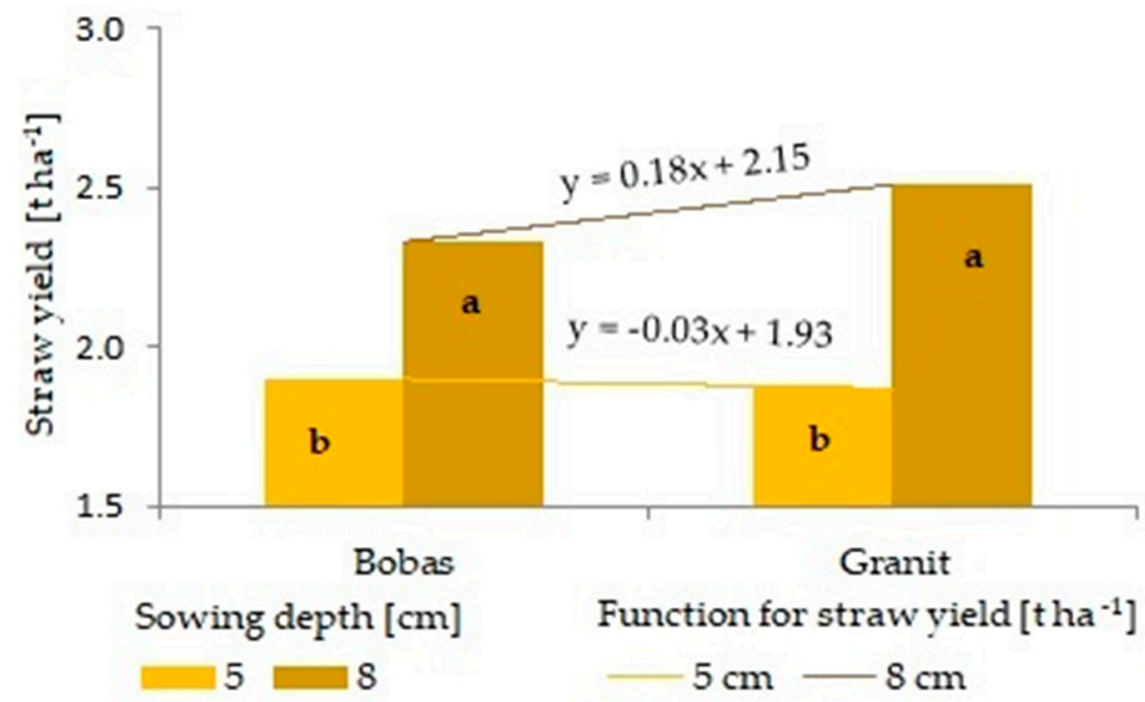

Figure 12. Straw yield in $2013(\mathrm{SDH} \times \mathrm{C})$. Different letters indicate significant differences between factors (Tukey's multiple range test).

Straw yield increased with deeper placement of seeds $(8 \mathrm{~cm})$ in all range of seeding rate. The highest straw yield was gained while using the most dense seeds at $1 \mathrm{~m}^{2}$ sown $8 \mathrm{~cm}$ deep (Figure 13).

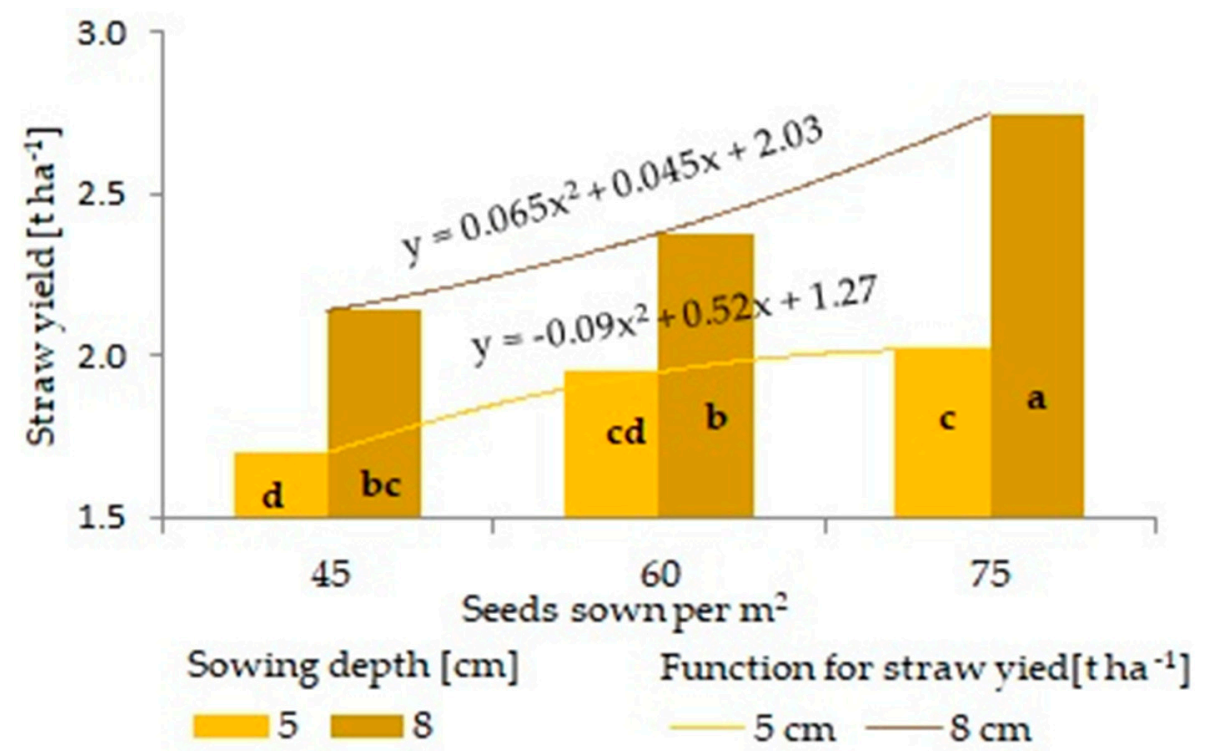

Figure 13. Straw yield in $2013(\mathrm{SDH} \times$ SDY). Different letters indicate significant differences between factors (Tukey's multiple range test).

\section{Discussion}

\subsection{The Effect of Weather Conditions on the Plant Development of Faba Bean}

Direct adverse effects of weather conditions (such as drought or high temperatures) can lead to abiotic stress in plants, which may contribute to the low yield stability of legumes [24]. Weather conditions affect the features determining plant density and yield components. Water requirements for faba beans during the growing season are estimated to be between 300-500 $\mathrm{mm}$ [24]. In our experiment, the annual precipitation ranged from 332.7 to $408.1 \mathrm{~mm}$, and therefore was favourable for faba bean production (Table 4, Figures 1-3). 
Taking into account thermal requirements, it can be defined as moderate. Generally, the germination and first stage growth of this plant is mainly related to temperature, especially daytime temperature when water is not a limiting factor. Low temperatures during the first stages of faba bean development can contribute to better vernalization and positively affect the root system expansion [24]. In turn, high temperature during ripening time can lead unfavourable to shortening this stage, influencing on seed yield quantity and quality. According to Pszczółkowska et al. [25] favourable moisture conditions in the emergence stage (BBCH10) had no inhibitory effect on germination and seed yield. According to Barłóg et al. [26] the growing season determines green seed yield. In turn, Podleśny [27] analyzed the effect of weather conditions on faba bean yield and stated that the greatest effect on yield was observed after rainfall in June during the flowering stage. In turn, Podleśny [27] claimed that cultivars of faba beans are characterized by different sensitivity to weather conditions. In our research, the greatest vegetative period concerned the year 2011 with 46 days and the shortest 39 days in 2013 with the highest total sum of precipitation $(116.4 \mathrm{~mm})$ (Table 4). The longest generative period was related to the year 2012, with 96 days for Bobas cultivar with the lowest sum of precipitation in this period (202.6 mm), what could be connected with the highest seed and straw yield. In López-Bellido et al. [14] review, in the early phases of vegetative growth, there can be found a linear correlation between dry matter accumulation and the sowing density per square meter. The length of the growing season and weather conditions during vegetative growth are important to the compensatory capacity of faba beans because they affect the number of stems per plant.

Days that allow to enter to the flowering stage are one of the most essential elements that can give information about faba bean duration longevity of the reproductive period. In our research, the generative period lasted on average 82 for Granit cultivar and 86 days for Bobas cultivar, the longest in 2012-96 days for indeterminate cultivar, and the shortest in 2013-75 days for determinate cultivar (Table 4).

According to Pszczółkowska et al. (2020) [25] at the stage of developed 3 leaves, the precipitation exceeded considerably the perennial average monthly precipitation, which negatively affected the seed yield. At the 6-7 leaf developed stage (BBCH 16-17/36-37), temperature had no significant effect on faba bean yield. Faba bean yield tended to decrease slightly $(R=-0.42)$. In our research the highest seed yield was obtained in the second year of experiment (2012), where the average temperature for the vegetative period amounted to $15.8^{\circ} \mathrm{C}$, while the highest temperature in this period was noted in $2013\left(17.4^{\circ} \mathrm{C}\right)$ with the lowest seed yield in 2013.

The time needed for plant seed germination depends on the sowing depth, size of seed, and the length of plumose and coleoptiles of individual plants $[17,28]$. Sowing too shallow may result in poor germination due to insufficient soil moisture in the upper layer of the soil, whereas deep sowing can lead to reduce plant emergence and yield [29]. Baye et al. [17] noticed that 7 days after sowing emergence was observed from seeds sown at depth 4 and $6 \mathrm{~cm}$, while after 12.5 days at $12 \mathrm{~cm}$ depth. In turn, Singh et al. [28] stated that medium depth $(8 \mathrm{~cm})$ took a longer time $(8.5$ days) for germination compared to $12 \mathrm{~cm}$ (7.8 days). Increasing depth of seeding according to this author expanded the days to set the first flowering prolonged. Shallow depth of sowing $(4 \mathrm{~cm})$ took the minimum time (around 59.3 days) compared to 8 and $12 \mathrm{~cm}$ of sowing depth to set the first flowering, which was prolonged. In turn, negative effect of sowing depth was observed by Nabi et al. [30] who stated that seedling emergence was reduced with increasing sowing depth in cotton cultivation. The deeper the seeds were sown, the more power they needed to push the shoots above the soil surface. Siddique and Loss [18] claimed in turn, that sowing depth had no effect on crop phenology of faba bean as well as in our studies. According to Ali et al. [19] sowing depth had also no significant effect on germinated seeds. In our study, there was no effect of sowing depth on the length of the vegetative period. The length of vegetative period was the same for both cultivars. 


\subsection{Effect of Examined Factors on Plant Density, Height of Plants before Harvest and Seed and Straw Yield}

Plant density is one of the primary factors controlling crop production. According to Jettner et al. [15] sowing seed rate can affect plant density, dry matter yield, plant height, seed yield, weed competition, the development of fungal and viral diseases, and radiation interception. In our research deeper sowing resulted in greater faba bean density in 2013 and lower number of plant per $\mathrm{m}^{2}$ before harvest in 2011. Increase sowing rate affected on larger plant density.

In Baye et al. [17], there was a significance difference in plant height between sowing depths. On the base of their research, the highest plant height was recorded in case of seeds sown at $8 \mathrm{~cm}$ depth, whereas the lowest at $12 \mathrm{~cm}$ planting depth. Similar results were obtained, taking into account 4 and $12 \mathrm{~cm}$ of sowing depth in Singh et al. study (2013) [28]. In our research at $8 \mathrm{~cm}$ depth, the plants of faba bean were higher in the year with the lowest precipitation during vegetative period. Divergent results were found in the year with the highest rainfall. In Al-Suhaibani et al. [31] research, no significant variation between the two varieties (Giza 716 and Giza 843) with respect to plant height was found. In our study, indeterminate cultivar (Bobas) was higher than determinate (Granit). According to Al. Suhaibani et al. (2013) [31] sowing density had a significant impact on various vegetative growth parameters, including plant height at 70 and 100 days after sowing. The low sowing density resulted in a decrease in plant height at 70 and 100 days after sowing, comparing to the high plant density (12 plants dripper $\left.{ }^{-1}\right)$, contradictory to our results.

According to Singh et al. [28], sowing depth has a significant impact on seed yield of faba bean. With the increase of depth in Singh et al. study [28], the yield of faba bean decreased. The greatest seed yield was obtained at a shallow depth of sowing $(4 \mathrm{~cm})$ gaining $3536.6 \mathrm{~kg} \mathrm{ha}^{-1}$ while the lowest $\left(3420.3 \mathrm{~kg} \mathrm{ha}^{-1}\right)$ with $12 \mathrm{~cm}$ of sowing depth. The study stood in agreement with our study where seed yield also decreased with increased sowing depth in 2011 and 2012. In turn, in the last year of experiment the results were opposite, greater yield was obtained at deeper sowing depth. According to Siddique and Loss [18] deep sowing did not reduce seed yield, and in some cases seed yield was higher with deeper sowing of chickpea and faba bean. The optimum sowing depth for field beans, according to these authors, is $5-8 \mathrm{~cm}$. Deep sowing can also contribute to improve crop establishment while moisture from summer and autumn precipitation is stored in the subsoil below $5 \mathrm{~cm}$, allowing for reduced damage from herbicides that are used immediately before or after sowing, and by improving the survival rate of Rhizobium inoculated on seeds due to more favourable soil conditions at depth.

According to Gasim et al. [32] the values of yield and yield components in faba bean inbred lines are different. These differences could be caused by genetic or genetic and environmental factors [32]. In Al-Suhaibani et al. [31] a significant difference between the two varieties in yield has been observed. Similar results were found in our research, where Bobas characterized by higher seed yield compared to Granit in all years of experiment.

Optimal sowing density contributes to increased yield and a reduction in the competition between plants for inputs. According to Aquilera-Diaz and Recalde-Manrique [33], increased plant density from 10 to 16 plants per $\mathrm{m}^{2}$ contributed to the seed yield increase, however, further increase to 21 plants per $\mathrm{m}^{2}$ did not cause significantly the increased of yield.

According to Dahmardeh et al. [34], increasing plants density from 12.5 to 20 plant per $\mathrm{m}^{2}$ contributed significantly to the biological yield increase. In our experiment, seed yield was significantly dependent on plant density only in 2013. Increasing the sowing rate from 45 to 60 seeds on $\mathrm{m}^{2}$ let to enhanced seed yield.

In Neugschwandtner et al. [8], straw yield may depend on the cultivar, which was confirmed by our study, where the indeterminate cultivar yielded higher in two years of the study. El-Sadek and Salem [35] found that higher seeding rates lead to higher straw yields, as also confirmed by our 2011 and 2013 field studies. 
Optimum sowing density depends on cultivars, species, number of branches, or time of sowing. According to Al-Suhaibani et al. [31], increasing sowing density contributed to a decrease in all yield components of individual plants of faba bean, but the yield had increased. In our research, the seed and straw yield have increased with increased sowing density. According to Mellendorf [36] the correlation between sowing density and yield can be described by two concepts. Maximum yield can be achieved if the plants are able to produce sufficient leaf area to ensure maximum light interception during reproductive growth. Secondly, the distance between plants maximises yield because it minimises plant-plant competition. Our results cannot be inscribed in this concept. Plant density is lower or higher compared to optimal results in lower yield, what cannot be proved by own research where a decrease of the yield has not been found. A reduction in yield caused by the high sowing density can be explained by competition between plants. The effect of sowing density on the growth and yield of faba beans may be characterized by differences in genotypes of faba bean.

According to Bond et al. [37], the recommended densities that are usually used range from 15 to 60 plants per $\mathrm{m}^{2}$, taking into account the cultivar and region, whereas in our study this was 60 and 75 seeds per $\mathrm{m}^{2}$.

\section{Conclusions}

Faba bean ( $V$. faba L. var. minor), next to peas and lupins, is a traditional Fabaceae crop grown in Poland and its productivity in such weather conditions can be promising. From the results of this study, Bobas (indeterminate cultivar) compared to Granit (determinate cultivar) had a longer growing season ( $2-5$ days), higher plants height, and seed yield. Therefore, it can be recommended to cultivate in conditions of south-west Poland.

It can be concluded that sowing depth had varying effect on faba bean yield. Earlier sown faba bean in lower temperatures during the vegetative period had a higher yield at shallow sowing depths. In turn, deeper seeding resulted in higher yield in case of delayed sowing. A slight tendency of higher seed yield under increased sowing was found. However, changing the number of seeds sown from 45 to 60 per $\mathrm{m}^{2}$ resulted in higher yields in the last year of the trial.

Author Contributions: Conceptualization, A.K., P.Z. and M.K.; methodology, A.K., M.K., L.K. and P.Z.; formal analysis, W.H.; investigation, P.Z., M.K., M.S.-A., W.H. and A.J.-R.; writing-original draft preparation, W.H., A.J.-R. and M.S.-A.; writing-review and editing, W.H., A.J.-R. and M.S.-A.; visualization, W.H. and M.S.-A.; supervision, A.K. and L.K. All authors have read and agreed to the published version of the manuscript.

Funding: The study was supported by the Leading Research Groups support project from the subsidy increased for the period 2020-2025 in the amount of $2 \%$ of the subsidy referred to Art. 387 (3) of the Law of 20 July 2018 on Higher Education and Science, obtained in 2019.

Institutional Review Board Statement: Not applicable.

Data Availability Statement: Not applicable.

Acknowledgments: Not applicable.

Conflicts of Interest: The authors declare no conflict of interest.

\section{References}

1. Wakweya, K.; Dargie, R.; Meleta, T. Effect of Sowing Date and Seed Rate on Faba Bean (Vicia faba L.) Growth, Yield and Components of Yield at Sinana, Highland Conditions of Bale, Southeastern Ethiopia. Int. J. Sci. Res. Agric. Sci. 2016, 3, 25-34. [CrossRef]

2. Mandal, U.K.; Singh, G.; Victor, U.S.; Sharma, K.L. Green manuring: Its effect on soil properties and crop growth under rice-Wheat cropping system. Eur. J. Agron. 2003, 19, 225-237. [CrossRef]

3. Crépon, K.; Marget, P.; Peyronnet, C.; Carrouée, B.; Arese, P.; Duc, G. Nutritional value of faba bean (Vicia faba L.) seeds for feed and food. Field Crop. Res. 2010, 115, 329-339. [CrossRef]

4. Vioque, J.; Alaiz, M.; Girón-Calle, J. Nutritional and functional properties of Vicia faba protein isolates and related fractions. Food Chem. 2012, 132, 67-72. [CrossRef] 
5. Landry, E.J.; Coyne, C.J.; Hu, J. Agronomic performance of spring-sown faba bean in Southeastern Washington. Agron. J. 2015, 107, 574-578. [CrossRef]

6. Jensen, E.S.; Peoples, M.B.; Hauggaard-Nielsen, H. Faba bean in cropping systems. Field Crop. Res. 2010, 115, 203-216. [CrossRef]

7. Galloway, J.N.; Dentener, F.J.; Capone, D.G.; Boyer, E.W.; Howarth, R.W.; Seitzinger, S.P.; Asner, G.P.; Cleveland, C.C.; Green, P.A.; Holland, E.A.; et al. Nitrogen Cycles: Past, Present, and Future. Biogeochemistry 2004, 70, 153-226. [CrossRef]

8. Neugschwandtner, R.; Ziegler, K.; Kriegner, S.; Wagentristl, H.; Kaul, H.P. Nitrogen yield and nitrogen fixation of winter faba beans. Acta Agric. Scand. Sect. B Soil Plant Sci. 2015, 65, 658-666. [CrossRef]

9. Salahin, N.; Alam, K.; Islam, M.; Naher, L.; Majid, N.M. Effects of green manure crops and tillage practice on maize and rice yields and soil properties. Aust. J. Crop Sci. 2013, 7, 1901-1911.

10. Prusiński, J.; Kaszkowiak, E.; Borowska, M. Effect of nitrogen fertilization and foliar application on faba bean seed yield and yield components. Fragm. Agron. 2008, 25, 111-127. (In Polish)

11. Śmiglak-Krajewska, M. Cultivation of Legume Crops in the Context of Sustainable Agriculture. Ann. Pol. Assoc. Agric. Agribus. Econ. 2018, 20, 255-261. [CrossRef]

12. Albayrak, S.; Türk, M.; Yüksel, O. Effect of row spacing and seeding rate on hungarian vetch yield and quality. Turk. J. Field Crop. 2011, 16, 54-55. [CrossRef]

13. Gezahegn, A.M.; Tesfaye, K.; Sharma, J.J.; Belel, M.D. Determination of optimum plant density for faba bean (Vicia faba L.) on vertisols at Haramaya, Eastern Ethiopia. Cogent Food Agric. 2016, 2. [CrossRef]

14. López-Bellido, F.J.; López-Bellido, L.; López-Bellido, R.J. Competition, growth and yield of faba bean (Vicia faba L.). Eur. J. Agron. 2005, 23, 359-378. [CrossRef]

15. Jettner, R.; Loss, S.P.; Martin, L.D.; Siddique, K.H.M. Responses of faba bean (Vicia faba L.) to sowing rate in south-western Australia II Canopy development, radiation absorption and dry matter partitioning. Aust. J. Agric. Res. 1998, 49, 999-1008. [CrossRef]

16. Mwanamwenge, J.; Loss, S.P.; Siddique, K.H.M.; Cocks, P.S. Growth, seed yield and water use of faba bean (Vicia faba L.) in a short-season Mediterranean-type environment. Aust. J. Exp. Agric. 1998, 38, 171-180. [CrossRef]

17. Baye, E.; Ebirahim, Z.; Kasahun, N.; Wasyihun, N.; Siyum, K.; Yachiso, D.; Tiruneh, Z.; Fekadu, B. Effects of Planting Depth on Germination and Growth of Faba Bean (Vicia faba L.) at Fitche, Oromia National Regional State, Central Ethiopia. Am. J. Agric. For. 2020, 8, 53863. [CrossRef]

18. Siddique, K.H.M.; Loss, S.P. Studies on sowing depth for chickpea (Cicer arietinum L.), faba bean (Vicia faba L.) and Lentil (Lens culinaris Medik) in a Mediterranean-type environment of south-western Australia. J. Agron. Crop Sci. 1999, 182, 105-112 [CrossRef]

19. Ali, S.A.M.; Idris, A.Y. Effect of Seed Size and Sowing Depth on Germination and Some Growth Parameters of Faba Bean (Vicia faba L.). Agric. Biol. Sci. J. 2015, 1, 1-5.

20. Gan, Y.T.; Miller, P.R.; McDonald, C.L. Response of kabuli chickpea to seed size and planting depth. Can. J. Plant Sci. 2003, 83, 39-46. [CrossRef]

21. IUSS Working Group WRB. World Reference Base for Soil Resources 2014, Update 2015 International Soil Classification System for Naming Soils and Creating Legends for Soil Maps. In World Soil Resources Reports; FAO: Rome, Italy, 2014; Volume 106, p. 192.

22. IUNG-PIB. Available online: http:/ / www.iung.pulawy.pl/ (accessed on 13 September 2020).

23. Meier, U. Growth Stages of Mono-and Dicotyledonous Plants; JKI: Quedlinburg, Germany, 2018. [CrossRef]

24. Kulig, B.; Kołodziej, J.; Oleksy, A.; Kołodziejczyk, M.; Sajdak, A. Influence of weather conditions on faba bean yielding. Ecol. Eng. 2011, 18, 1071-1078.

25. Pszczółkowska, A.; Okorski, A.; Fordonski, G.; Kotecki, A.; Kozak, M.; Dzienis, G. Effect of weather conditions on yield and health status of faba bean seeds in Poland. Agronomy 2020, 10, 48. [CrossRef]

26. Barłóg, P.; Grzebisz, W.; Łukowiak, R. Faba bean yield and growth dynamics in response to soil potassium availability and sulfur application. Field Crop. Res. 2018, 219, 87-97. [CrossRef]

27. Podleśny, J. Effect of amount and distribution of precipitation during vegetation on growth, development and yielding of determinate and traditional faba bean varieties. Acta Agroph. 2009, 14, 413-425.

28. Singh, A.K.; Bhatt, B.P.; Sundaram, P.K.; Gupta, A.K.; Singh, D. Planting geometry to optimize growth and productivity in faba bean (Vicia faba L.) and soil fertility. J. Environ. Biol. 2013, 34, 117-122. [PubMed]

29. Aikins, S.H.M.; Afuakwa, J.J.; Baidoo, D. Effect of planting depth on maize stand establishment. Ghana Inst. Eng. 2006, 4, 20-25.

30. Nabi, G.; Mullins, C.E.; Montemayor, M.B.; Akhtar, M.S. Germination and Emergence of irrigated Cotton in Pakistan in relation to Sowing Depth and Physical proprieties of the Seedbed. Soil Tillage Res. 2001, 59, 33-44. [CrossRef]

31. Al-Suhaibani, N.; El-Hendawy, S.; Schmidhalter, U. Influence of varied plant density on growth, yield and economic return of drip irrigated faba bean (Vicia faba L.). Turk. J. Field Crop. 2013, 18, 185-197.

32. Gasim, S.; Hamad, S.A.A.; Abdelmula, A.; Mohamed Ahmed, I.A. Yield and quality attributes of faba bean inbred lines grown under marginal environmental conditions of Sudan. Food Sci. Nutr. 2015, 3, 539-547. [CrossRef]

33. Aguilera-Diaz, C.; Recalde-Manrique, R. Effects of plant density and inorganic nitrogen fertilizer on field beans (Vicia faba). J. Agric. Sci. 1995, 125, 87-93. [CrossRef]

34. Dahmardeh, M.; Ramroodi, M.; Valizadeh, J. Effect of plant density and cultivars on growth, yield and yield components of faba bean (Vicia faba L.). Afr. J. Biotechnol. 2010, 9, 5. 
35. El-Sadek, A.; Salem, E. Impact of ridge-Furrow water harvesting system on faba bean (Vicia faba L.) production under rainfed conditions in Matrouh, Egypt. Ann. Agric. Sci. 2015, 60, 61-66. [CrossRef]

36. Mellendorf, E.N. Soybean Growth and Yield Response to Interplant Competition Relief in Various Plant Density Environments. Master's Thesis, University of Illinois at Urbana-Champaign, Champaign, IL, USA, 2011; p. 85.

37. Bond, D.A.; Lawes, D.A.; Hawtin, G.C.; Saxena, M.C.; Stephens, J.H. Faba Bean (Vicia faba L.). In Grain Legume Crops; Smmerfield, R.J., Roberts, E.H., Eds.; Collins: London, UK, 1985; pp. 199-265. 